\title{
Apigenin Ameliorates Oxidative Stress-induced Neuronal Apoptosis in SH-SY5Y Cells
}

\author{
Yeo Jin Kim ${ }^{1}$, Eun Ju Cho', Ah Young Lee ${ }^{2 *}$, and Weon Taek Seo ${ }^{2 *}$ \\ ${ }^{1}$ Department of Food Science and Nutrition and Kimchi Research Institute, Pusan National University, Busan 46241, Republic of Korea \\ ${ }^{2}$ Department of Food Science, Gyeongsang National University, Jinju 52725, Republic of Korea
}

Received: September 9, 2020 / Revised: January 6, 2021 / Accepted: January 14, 2021

\begin{abstract}
The overproduction of reactive nitrogen species (RNS) and reactive oxygen species (ROS) causes oxidative damage to neuronal cells, leading to the progression of neurodegenerative diseases. In this study, we determined the nitric oxide radical (NO), hydroxyl radical $(\cdot \mathrm{OH})$, and superoxide anion radical $\left(\mathrm{O}_{2}^{-}\right)$scavenging activities of apigenin. Our results showed that apigenin exhibited remarkable, concentration-dependent $\cdot \mathrm{OH}, \mathrm{O}_{2}^{-}$, and NO radical scavenging activities. Particularly, apigenin indicated the strongest $\cdot \mathrm{OH}$ radical scavenging activity with $93.38 \%$ in the concentration of $100 \mu \mathrm{M}$. Furthermore, we also investigated the protective effects of apigenin against hydrogen peroxide $\left(\mathrm{H}_{2} \mathrm{O}_{2}\right)$-induced oxidative stress in SH-SY5Y cells. The $\mathrm{H}_{2} \mathrm{O}_{2}$ treatment resulted in a significant decrease in cell viability, as well as an increase in lactate dehydrogenase (LDH) release and ROS production compared with the $\mathrm{H}_{2} \mathrm{O}_{2}$-nontreated $\mathrm{SH}-\mathrm{SY} 5 \mathrm{Y}$ cells. However, the cell viability significantly increased in the apigenin-treated group, as well as inhibited ROS generation and $\mathrm{LDH}$ release compared with the $\mathrm{H}_{2} \mathrm{O}_{2}$-induced control group. To elucidate the protective mechanisms of apigenin against oxidative stress in SH-SY5Y, we analyzed the apoptosis-related protein expression. The apigenin treatment resulted in the downregulated expression of apoptosis-related protein markers, such as cytochrome C, cleaved caspase-3, poly (ADP)-ribose polymerase (PARP), and B-cell lymphoma 2-associated $\mathrm{X}(\mathrm{Bax})$, as well as the upregulated expression of anti-apoptosis markers such as B-cell lymphoma 2 (Bcl-2). In this study, we report that apigenin exhibits a neuroprotective effect against oxidative stress in SH-SY5Y cells. These results suggest that apigenin may be considered as a potential agent for neurodegenerative disease prevention.
\end{abstract}

Keywords: Hydrogen peroxide, neuronal, neurodegenerative disease, neuroprotection, oxidative stress

\section{Introduction}

Oxidative stress is defined as out of balance between the elimination and production of reactive oxygen species (ROS) and reactive nitrogen species (RNS) [1]. ROS and RNS, such as hydroxyl radical $(\cdot \mathrm{OH})$, nitric oxide radical (NO), hydrogen peroxide $\left(\mathrm{H}_{2} \mathrm{O}_{2}\right)$, and superoxide

\footnotetext{
*Corresponding authors

A. Y. Lee

Tel: +82-55-772-3278, Fax: +82-55-772-3279

E-mail: aylee@gnu.ac.kr

W. T. Seo

Tel: +82-55-772-3276, Fax: +82-55-772-3279

E-mail: wtseo@gnu.ac.kr
}

anion radical $\left(\mathrm{O}_{2}^{-}\right)$are produced by external environmental factors and biochemical reactions [2]. Moderate levels of ROS and RNS play an essential role, either directly or indirectly, in health through mechanisms including cellular signaling, biosynthetic processes, and host defenses [3]. However, overproduction of ROS and RNS is thought to be responsible for damages to lipids, proteins, and DNA, leading to oxidative stress [4]. Oxidative stress can induce neuronal apoptosis and neuroinflammation in brain cells, resulting in neurodegenerative diseases such as Alzheimer's disease (AD) and Parkinson's disease (PD) [5, 6]. The brain is especially more vulnerable to oxidative stress than other organs, on account of its high oxygen consumption and 
amount of polyunsaturated fatty acids. The neurons are especially sensitive to free radicals, which can lead to cell death [7].

SH-SY5Y neuronal cells have been widely used to characterize neuron-like behavior when investigating potential neuroprotective activity [8]. Recently, studies have confirmed that oxidative stress contributes to apoptosis and inflammation in SH-SY5Y neuronal cells [9, 10]. $\mathrm{H}_{2} \mathrm{O}_{2}$ is related to pathological processes of chronic and acute neuronal toxicity [11]. ROS production and apoptosis-related protein expression of Bax, caspase-3 and cytochrome $\mathrm{C}$ are induced by $\mathrm{H}_{2} \mathrm{O}_{2}$ in SH-SY5Y cells [12]. Therefore, $\mathrm{H}_{2} \mathrm{O}_{2}$-induced SH-SY5Y cells are well used to research the promising agents with protective effects from oxidative stress.

Apigenin (4',5,7-trihydroxyflavone), non-mutagenic and non-toxic natural plant flavonoid, is found widely in plants, vegetables, tea leaves, and fruits [13, 14]. Previous studies demonstrated that apigenin has beneficial effects, such as anti-oxidant [15], anti-inflammation [16], anti-apoptosis activity [17], and anti-cancer properties [18]. In addition, administration of apigenin improved the memory deficit of amyloid beta $(\mathrm{A} \beta)$ transgenic mice [19]. Apigenin attenuated lipopolysaccharideinduced myocardial damage by inhibiting inflammatory cytokines and their regulatory factor, nuclear factor kappa B [20]. Apigenin has also been reported to inhibit apoptosis through the regulation of mitogen-activated protein kinase (MAPK) induced by A $\beta$ in neuronal cells [21]. However, the protective effect of apigenin for $\mathrm{H}_{2} \mathrm{O}_{2}$ induced neurotoxicity and neuronal apoptosis in $\mathrm{SH}$ SY5Y cells have not been examined yet. Thus, the current study investigated the $\mathrm{O}_{2}^{-}, \cdot \mathrm{OH}$, and $\mathrm{NO}$ radical scavenging effects of apigenin in vitro. In addition, the protective effect and underlying mechanisms of apigenin against oxidative damage induced by $\mathrm{H}_{2} \mathrm{O}_{2}$ were confirmed using SH-SY5Y neuronal cells.

\section{Materials and Methods}

\section{Reagents}

Dimethyl sulfoxide (DMSO), 3-(4,5-dimethylthiazol-2yl)-2,5-diphenyltetrazolium bromide (MTT), and 2',7'dichloro-fluorescein diacetate (DCF-DA) were obtained from Sigma-Aldrich Inc. (USA). Sodium pentacyanonitrosylferrate (III) dihydrate (SNP) and $\mathrm{H}_{2} \mathrm{O}_{2}$ were supplied by Junsei Chemical Co. (Japan). The LDH cytotoxicity detection kit was obtained from Takara Bio (Japan). Trichloroacetic acid (TCA) was purchased from Biosesang Inc. (Korea). Radioimmunoprecipitation assay (RIPA) buffer was purchased from Elpis Biotech. (Korea). Phenazine methosulfate (PMS) and NADH were obtained from Bio Basic Inc. (USA). Polyvinylidene fluoride (PVDF) membrane was obtained from Millipore Co. (USA). Thiobarbituric acid (TBA) was purchased from Acros Organics Inc. (USA).

\section{Sample preparation}

Apigenin (4',5,7-trihydroxyflavone) was obtained from Sigma-Aldrich Inc. and had a purity $>95 \%$ based on HPLC analysis. Apigenin was dissolved in DMSO as a stock solution and diluted with dulbecco's modified eagle's medium (DMEM) prior to use.

\section{.OH scavenging assay}

$\mathrm{OH}$ radical scavenging activity was determined follow to the method reported by Chung et al. [22]. Various concentrations of apigenin $(25,50,100$, and $250 \mu \mathrm{M})$ were added to the reaction mixture containing $10 \mathrm{mM} \mathrm{H}_{2} \mathrm{O}_{2}$ and $10 \mathrm{mM} \mathrm{FeSO}_{4} \cdot \mathrm{H}_{2} \mathrm{O}$-EDTA with $10 \mathrm{mM}$ 2-deoxyribose solution and incubated at $37^{\circ} \mathrm{C}$ for $4 \mathrm{~h}$. After incubation, $1.0 \%$ TBA and $2.8 \%$ TCA were added to the mixture and boiled for $20 \mathrm{~min}$ at $100^{\circ} \mathrm{C}$. $\mathrm{OH}$ radical scavenging ability was measured at $490 \mathrm{~nm}$ by an RT-6100 microplate reader (Rayto Life and Analytical Sciences Co. Ltd., China).

\section{$\mathrm{O}_{2}{ }^{-}$scavenging assay}

$\mathrm{O}_{2}^{-}$radical scavenging activity was estimated in accordance of the method reported by Nishikimi et al. [23]. Various concentrations of apigenin (25, 50, 100, and $250 \mu \mathrm{M})$ were added to the reaction mixture containing $100 \mu \mathrm{l}$ of $0.1 \mathrm{M}$ Tris- $\mathrm{HCl}$ (pH 7.4), $200 \mu \mathrm{l}$ of $100 \mathrm{mM}$ PMS, $400 \mu \mathrm{l}$ of $500 \mathrm{mM} \mathrm{NADH}$ and $200 \mu \mathrm{l}$ of $0.5 \mathrm{mM}$ NBT. After $10 \mathrm{~min}$, the absorbance was read at $560 \mathrm{~nm}$ utilizing an RT-6100 microplate reader (Rayto Life and Analytical Sciences Co. Ltd.).

\section{NO scavenging assay}

The NO radical scavenging activity of apigenin was measured following to the method reported by Marcocci et al. [24]. Various concentrations of apigenin (25, 50, 
100 , and $250 \mu \mathrm{M}$ ) diluted in $\mathrm{MeOH}$ were mixed with $10 \mathrm{mM}$ SNP, and incubated at room temperature for $150 \mathrm{~min}$. Griess reagent was added at a ratio of $1: 1$ in a 96 -well plate for $30 \mathrm{~min}$ at room temperature. The absorbance was measured at $540 \mathrm{~nm}$ using an RT-6100 microplate reader (Rayto Life and Analytical Sciences Co. Ltd.).

\section{Cell culture}

SH-SY5Y cells were purchased from KCLB (Korea Cell Line Bank, Korea). The cells were cultured with 100 units/ml penicillin-streptomycin and 10\% fatal bovine serum based DMEM at $37^{\circ} \mathrm{C}$ with $5 \% \mathrm{CO}_{2}$ in an incubator. The culture medium was replaced three times per week. Cells were sub-cultured with $0.05 \%$ trypsin-EDTA in phosphate buffered saline (PBS). Cells were used for experimentation when confluence was $\sim 80 \%$.

\section{MTT assay}

Cells were seeded in a 96-well plate that at a density of $5 \times 10^{4}$ cells $/ \mathrm{ml}$ and cultured for $24 \mathrm{~h}$. The cells were treated with different concentrations of apigenin (0.1, 0.5 , and $1 \mu \mathrm{M}$ ) for $3 \mathrm{~h}$, followed by $300 \mu \mathrm{M}$ of $\mathrm{H}_{2} \mathrm{O}_{2}$ treatment for $24 \mathrm{~h}$ to induce oxidative stress. After incubation, $5 \mathrm{mg} / \mathrm{ml}$ MTT solution was added and allowed to react for $4 \mathrm{~h}$. The incorporated formazan crystals in the viable cells were solubilized using DMSO. The absorbance was read at $540 \mathrm{~nm}$ using an RT-6100 microplate reader (Rayto Life and Analytical Sciences Co. Ltd.).

\section{DCF-DA assay}

To measure the ROS scavenging activity, the DCF-DA assay was used [25]. SH-SY5Y cells were seeded in 96well plate at a density of $5 \times 10^{4}$ cells $/ \mathrm{ml}$ and cultured for $24 \mathrm{~h}$. Apigenin was added to each well in diverse concentrations $(0.1,0.5$, and $1 \mu \mathrm{M})$ and incubated for $3 \mathrm{~h}$. To induce oxidative stress, $300 \mu \mathrm{M}$ of $\mathrm{H}_{2} \mathrm{O}_{2}$ was added for $24 \mathrm{~h}$. After incubation, $80 \mu \mathrm{M}$ DCF-DA was added and left to react for $30 \mathrm{~min}$. Fluorescence was read using a fluorescence spectrophotometer (FLUOstar OPTIMA, BMG Labtech, Germany) at an excitation of $480 \mathrm{~nm}$ and an emission of $535 \mathrm{~nm}$.

\section{LDH release assay}

SH-SY5Y cells were seeded in a 96 -well plate at a density of $5 \times 10^{4}$ cells $/ \mathrm{ml}$. Apigenin $(0.1,0.5$, and $1 \mu \mathrm{M})$ was added for $3 \mathrm{~h}$, followed by treatment with $300 \mu \mathrm{M}$ $\mathrm{H}_{2} \mathrm{O}_{2}$. The supernatant and reaction mix were added to a 96-well plate and incubated at room temperature for $30 \mathrm{~min}$. Absorbance was read at $540 \mathrm{~nm}$ by an RT-6100 microplate reader (Rayto Life and Analytical Sciences Co. Ltd.).

\section{Western blotting analysis}

SH-SY5Y cells were seeded in a cell culture dish and incubated for $24 \mathrm{~h}$. After incubation, the cells were pretreated with apigenin $(0.1,0.5$, and $1 \mu \mathrm{M})$ for $3 \mathrm{~h}$ and treated with $300 \mu \mathrm{M}$ of $\mathrm{H}_{2} \mathrm{O}_{2}$ for another $24 \mathrm{~h}$. Protein extracts from the SH-SY5Y cells were prepared using lysis buffer. Proteins were separated by electrophoresis using $10 \%$ or $13 \%$ sodium dodecyl sulfate polyacrylamide gels (SDS-PAGE), then transferred to the PVDF membranes. Proteins were blocked using 5\% skimmed milk for $60 \mathrm{~min}$, and washed with PBS. Membranes were incubated with the primary antibody overnight at $4^{\circ} \mathrm{C}$ [each antibody at a dilution of 1:1000; poly (ADP)ribose polymerase (PARP), cleaved caspase-3, cytochrome C, B-cell lymphoma 2-associated X (Bax), B-cell lymphoma 2 (Bcl-2), and $\beta$-actin]. Membranes were then incubated with the appropriate HRP-conjugated secondary antibodies for $1 \mathrm{~h}$. Expression of protein was visualized utilizing a chemiluminescent imaging system (Davinci Chemi, Korea).

\section{Statistical analysis}

Results were stated as means \pm standard deviation (SD). SPSS (version 25; SPSS Inc., USA) was used to perform analysis of variance (ANOVA), followed by

Table 1. $. \mathrm{OH}, \mathrm{O}_{2}{ }^{-}$, and NO radical scavenging activity of apigenin.

\begin{tabular}{cccc}
\hline \multirow{2}{*}{$\begin{array}{c}\text { Treatment } \\
(\mu \mathrm{M})\end{array}$} & \multicolumn{3}{c}{ Scavenging activity (\%) } \\
\cline { 2 - 4 } & \multicolumn{1}{c}{ OH radical } & \multicolumn{1}{c}{$\mathrm{O}_{2}^{-}$radical } & \multicolumn{1}{c}{ NO radical } \\
\hline 25 & $91.72 \pm 0.35^{\mathrm{b}}$ & $3.33 \pm 0.79^{\mathrm{d}}$ & $42.15 \pm 0.29^{\mathrm{d}}$ \\
50 & $93.00 \pm 0.46^{\mathrm{a}}$ & $9.62 \pm 1.00^{\mathrm{c}}$ & $46.32 \pm 0.57^{\mathrm{c}}$ \\
100 & $93.38 \pm 0.25^{\mathrm{a}}$ & $17.41 \pm 1.11^{\mathrm{b}}$ & $48.93 \pm 0.57^{\mathrm{b}}$ \\
250 & $92.75 \pm 0.56^{\mathrm{a}}$ & $32.14 \pm 1.35^{\mathrm{a}}$ & $50.34 \pm 0.35^{\mathrm{a}}$ \\
\hline
\end{tabular}

Values are mean $\pm S D$.

${ }^{a-d}$ Means are significantly different $(p<0.05)$ by Duncan's multiple range test. 
Duncan's post-hoc tests. Significance was set at $p<0.05$.

\section{Results}

\section{Effect of apigenin on $\cdot \mathrm{OH}, \mathrm{O}_{2}^{-}$, and $\mathrm{NO}$ radical scavenging activity}

The $\mathrm{OH}, \mathrm{O}_{2}^{-}$, $\mathrm{NO}$ radical scavenging activity of apigenin is shown in Table 1. All concentrations of apigenin $(25,50,100$, and $250 \mu \mathrm{M})$ showed more than $90 \% \cdot \mathrm{OH}$ radical scavenging activities. Of note, the strongest $\cdot \mathrm{OH}$ radical scavenging activity was $93.38 \%$ at the concentration of $100 \mu \mathrm{M}$. Apigenin also showed $\mathrm{O}_{2}{ }^{-}$radical scavenging ability concentration-dependently. Apigenin revealed dose-dependent radical scavenging activity against NO. Furthermore, apigenin showed a NO radical scavenging effect of $50.34 \%$ at $250 \mu \mathrm{M}$. Therefore, apigenin has antioxidant capabilities by the scavenging of $\mathrm{OH}, \mathrm{O}_{2}^{-}$, and $\mathrm{NO}$ radicals.

\section{Protective effect of apigenin on cell viability in SH-SY5Y cells treated with $\mathrm{H}_{\mathbf{2}} \mathrm{O}_{2}$}

The effect of apigenin on cell viability of SH-SY5Y cells treated with $\mathrm{H}_{2} \mathrm{O}_{2}$ was investigated by the MTT assay (Fig. 1). The results indicated that $\mathrm{H}_{2} \mathrm{O}_{2}$-treated cells were significantly decreased cell viability to $50.26 \%$ compared to $\mathrm{H}_{2} \mathrm{O}_{2}$-non treated cells $(100 \%)$. However, treatment with apigenin increased cell viability to $66.28 \%$, $82.69 \%$, and $85.16 \%$ at $0.1,0.5$, and $1 \mu \mathrm{M}$, respectively.

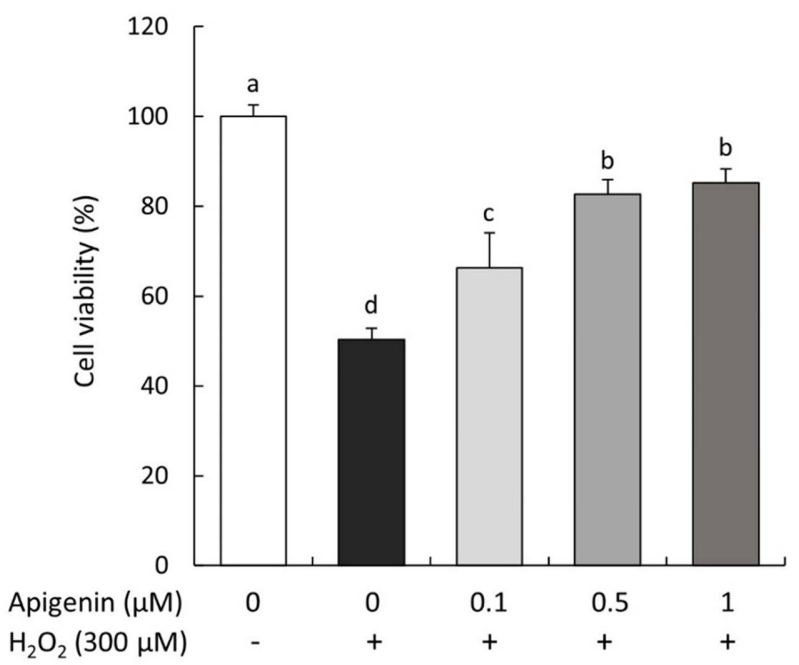

Fig. 1. Effect of apigenin on cell viability in SH-SY5Y cells treated with $\mathrm{H}_{2} \mathrm{O}_{2}$. Values are mean $\pm \mathrm{SD}$. ${ }^{\text {a-d }}$ Means are significantly different $(p<0.05)$ by Duncan's multiple range test.
These results indicated that apigenin had protective effect from $\mathrm{H}_{2} \mathrm{O}_{2}$-induced cell death in $\mathrm{SH}-\mathrm{SY} 5 \mathrm{Y}$ cells.

\section{Protective effect of apigenin on ROS release in SH-SY5Y} cells treated with $\mathrm{H}_{2} \mathrm{O}_{2}$

To establish the protective effect of apigenin on ROS generation in $\mathrm{H}_{2} \mathrm{O}_{2}$-induced $\mathrm{SH}$-SY5Y cells, the DCF-DA assay was performed. After $60 \mathrm{~min}$, ROS production was increased in the $\mathrm{H}_{2} \mathrm{O}_{2}$-treated cells compared to the $\mathrm{H}_{2} \mathrm{O}_{2}$-non treated cells, indicating that $\mathrm{H}_{2} \mathrm{O}_{2}$ induced ROS overproduction (Fig. 2A). Compared to $100 \%$ of the
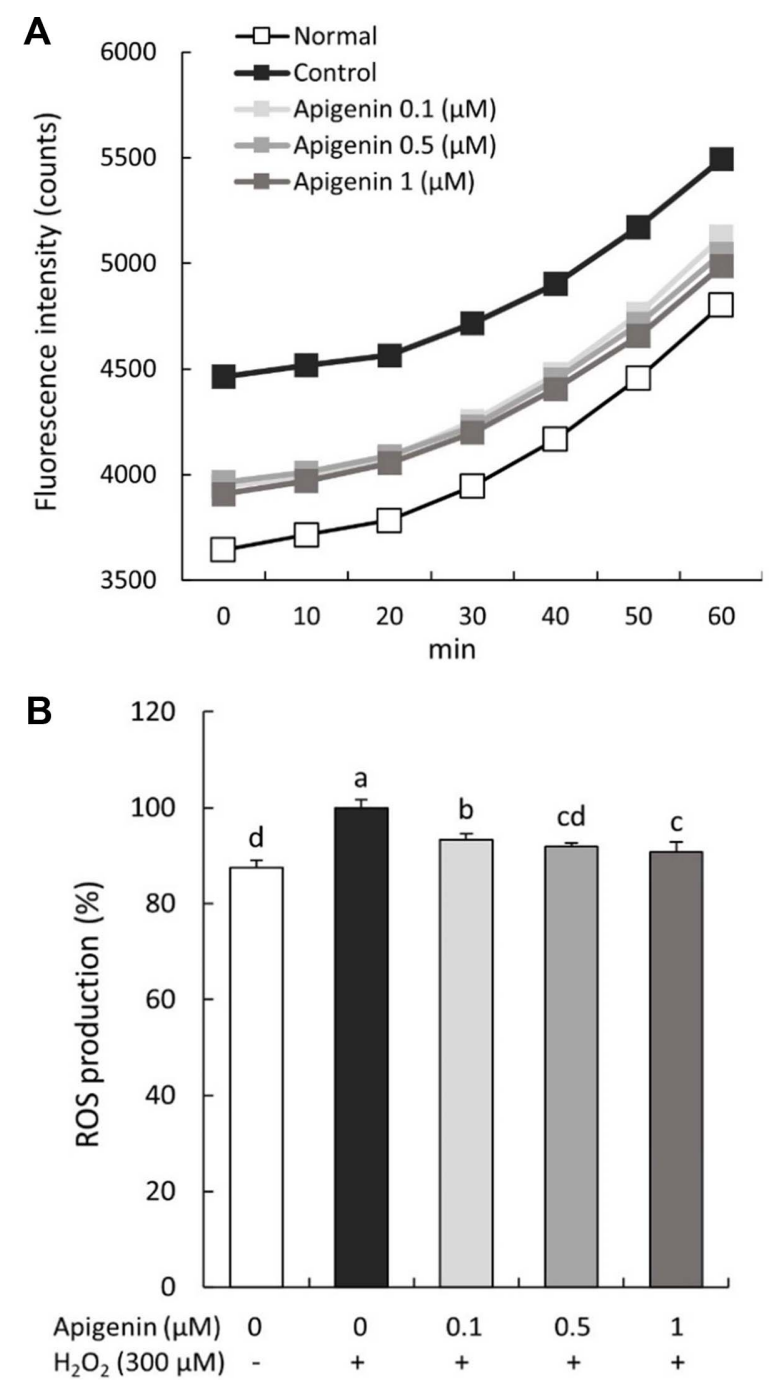

Fig. 2. Effect of apigenin on ROS production in SH-SY5Y cells treated with $\mathbf{H}_{\mathbf{2}} \mathrm{O}_{2}$. Time course of change in intensity of DCF fluorescence during $60 \mathrm{~min}(\mathrm{~A})$. Intensity of ROS production at $60 \mathrm{~min}(B)$. Values are mean $\pm S D .{ }^{a-d}$ Means are significantly different $(p<0.05)$ by Duncan's multiple range test. 


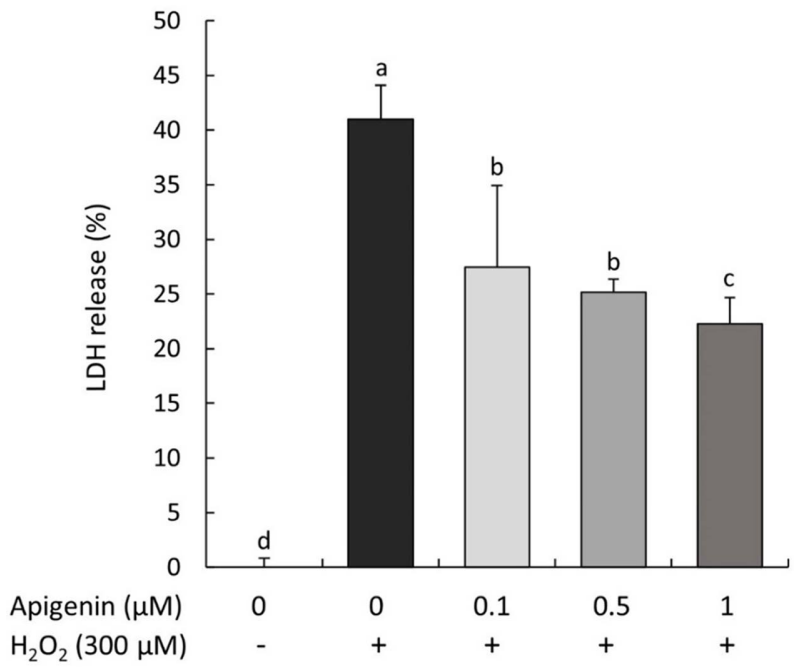

Fig. 3. Effect of apigenin on LDH release in SH-SY5Y cells treated with $\mathrm{H}_{2} \mathrm{O}_{2}$. Values are mean \pm SD. ${ }^{\mathrm{a}-\mathrm{d}}$ Means are significantly different $(p<0.05)$ by Duncan's multiple range test.

$300 \mu \mathrm{M} \mathrm{H}_{2} \mathrm{O}_{2}$-only treated group, ROS production in the non-treated group was $87.47 \%$ (Fig. 2B). Whereas treatment of the cells with apigenin showed inhibitory effects on ROS formation, showing $93.33 \%, 91.89 \%$, and $90.82 \%$ at concentrations of $0.1,0.5$, and $1 \mu \mathrm{M}$, respectively. These results confirmed that ROS generation in SHSY5Y neuronal cells treated with $\mathrm{H}_{2} \mathrm{O}_{2}$ was attenuated by apigenin.

\section{Protective effect of apigenin on LDH elimination in SH- SY5Y cells treated with $\mathrm{H}_{2} \mathrm{O}_{2}$}

The inhibitory effect of apigenin on $\mathrm{LDH}$ release in $\mathrm{H}_{2} \mathrm{O}_{2}$-treated SH-SY5Y cells was shown in Fig. 3. The levels of $\mathrm{LDH}$ were significantly increased in the group treated with only $\mathrm{H}_{2} \mathrm{O}_{2}(40.99 \%)$ compared to nontreated group $(0.84 \%)$. However, treatment with apigenin $(0.1,0.5$, and $1 \mu \mathrm{M})$ significantly inhibited $\mathrm{LDH}$ release by $27.49 \%, 25.18 \%$, and $22.31 \%$, respectively. These finding suggest that apigenin has protective effect against neuronal oxidative damage caused by $\mathrm{H}_{2} \mathrm{O}_{2}$.

\section{Protective effect of apigenin on apoptosis-related protein expressions in SH-SY5Y cells treated with $\mathrm{H}_{2} \mathrm{O}_{2}$}

To confirm the protective mechanisms of apigenin against $\mathrm{H}_{2} \mathrm{O}_{2}$-induced apoptosis, we examined cytochrome C, cleaved caspase-3, cleaved PARP/PARP, and Bax/Bcl-2 protein expression by Western blotting in SH-
SY5Y cells treated with $\mathrm{H}_{2} \mathrm{O}_{2}$ (Fig. 4). In our results, the increase of Bax expression and decrease of Bcl-2 expression were observed, in $\mathrm{H}_{2} \mathrm{O}_{2}$-treated control groups, resulting in significant increase in the Bax/Bcl-2 protein ratio. However, apigenin-treated groups showed a downregulation of the $\mathrm{Bax} / \mathrm{Bcl}-2$ levels, which was similar to the $\mathrm{H}_{2} \mathrm{O}_{2}$-non treated group. In addition, the protein levels of cleaved PARP/PARP, cytochrome $\mathrm{C}$, and cleaved caspase-3 were significantly increased in the $\mathrm{H}_{2} \mathrm{O}_{2}$-induced control cells compared with the $\mathrm{H}_{2} \mathrm{O}_{2}$-non induced cells. Nevertheless, the levels of cytochrome C, cleaved PARP/PARP, and cleaved caspase-3 protein expression were significantly decreased in apigenintreated groups. In this study, our results indicated that apigenin protected from oxidative stress-induced neuronal cell death via regulation of the apoptosis signaling pathway.

\section{Discussion}

ROS and RNS play an important part in physiological functions, acting as molecular signals in the body. Overproduction of ROS and RNS are causative of harmful reactions, which are associated with a high risk of oxidative damage to organs, resulting in the progression of degenerative diseases [26]. In particular, oxidative stress in the brain is strongly connected in neurodegenerative diseases which are AD, $\mathrm{PD}$, and Huntington's disease [27]. The brain is insufficient for oxidative defense system and is more vulnerable to oxidative stress than other organs. Therefore, lipids, proteins, and DNA can be damaged by excessive production of ROS and RNS in the brain [7, 28]. Many previous studies have indicated that supplements of anti-oxidant may prevent the progression of neurodegenerative diseases, and may mitigate ROS-induced neuronal damage [27, 29]. Notably, natural anti-oxidants isolated from various plants are receiving more attention for the prevention and treatment of neurodegenerative disorders [30,31]. Apigenin, one of the flavonoids with low toxicity, is found widely in plants, such as parsley, onions, oranges, and herb teas [13, 14]. Apigenin has been reported to have various beneficial effects including anti-apoptotic, antiinflammatory, and anti-bacterial effects [14, 16, 32]. According to Balez et al. [33], apigenin possessed neuroprotective effects against inflammation, apoptosis in 

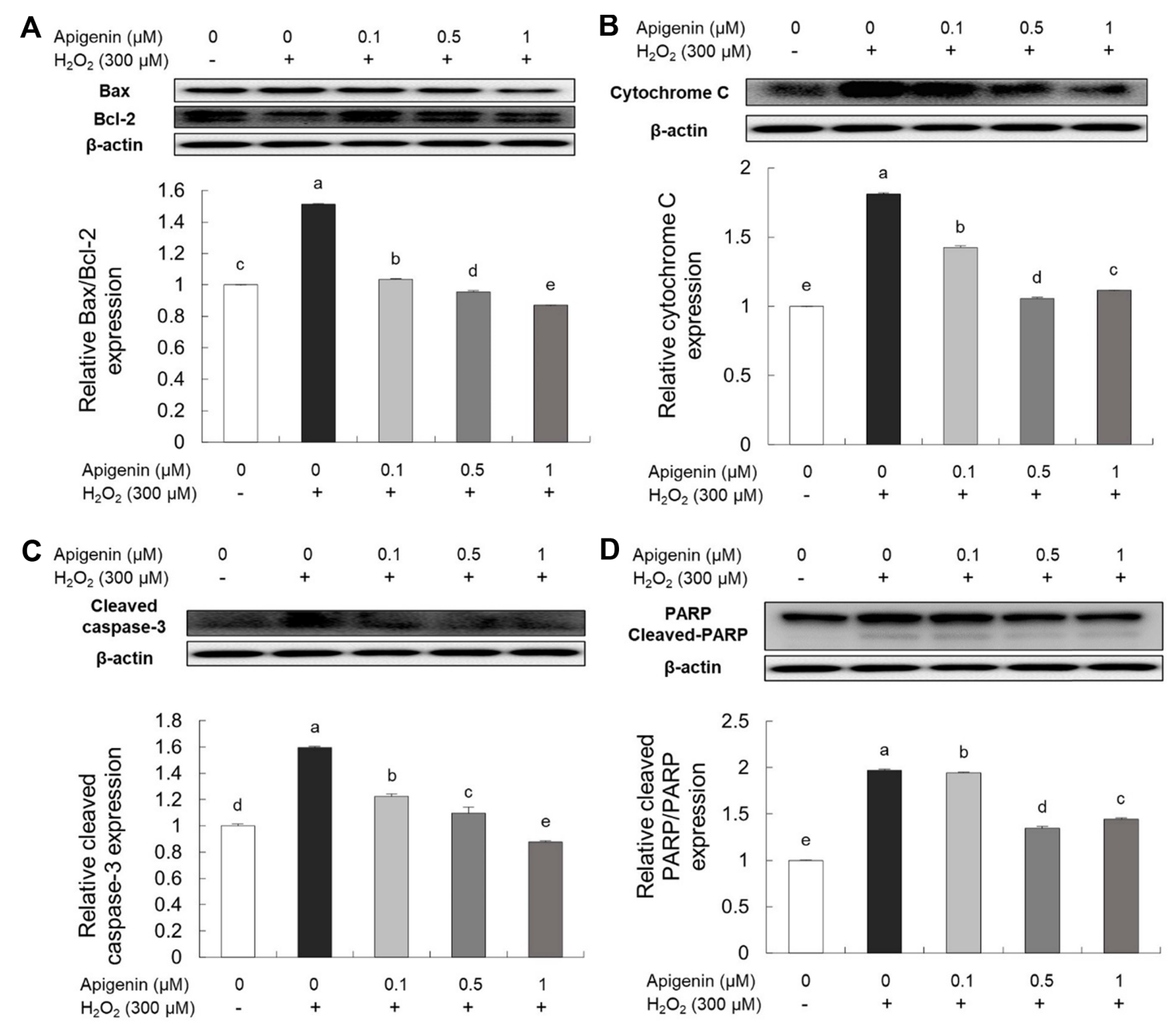

Fig. 4. Effects of apigenin on the levels of Bax/Bcl-2 (A) cytochrome $\mathrm{C}$ (B) cleaved caspase-3 (C) cleaved PARP/PARP (D) protein expression in SH-SY5Y cells treated with $\mathbf{H}_{\mathbf{2}} \mathbf{O}_{2}$. Bax, B-cell lymphoma 2-associated X; Bcl-2, B-cell lymphoma 2; cytochrome C; cleaved caspase-3; PARP, poly (ADP)-ribose polymerase. Values are mean \pm SD. ${ }^{a-e}$ Means are significantly different $(p<0.05)$ by Duncan's multiple range test. $\beta$-actin was used as a loading control.

induced pluripotent stem cell-derived neurons by attenuating $\mathrm{Ca}^{2+}$ signaling and caspase-3/7 activity. In addition, apigenin protected neuronal apoptosis by inhibiting the caspase-3 activity in $\mathrm{H}_{2} \mathrm{O}_{2}$-treated $\mathrm{SH}-\mathrm{SY} 5 \mathrm{Y}$ neuronal cells [34]. As mentioned above, oxidative stress is an imbalance of oxidant and antioxidant defense systems caused by stressors of external and internal in the body. In addition, neurons in the brain are confirmed fastest degenerated, due to the lack of an antioxidant defense system than other institutions and susceptible to oxidative stress [35, 36]. Consistent with these reports, that oxidative stress caused by ROS interferes with cell function and ultimately leads to cell death [37]. Previous study has confirmed that $\mathrm{AD}$ patients had increased levels of oxidative stress in the cells which the most vulnerable areas of the brain tissue [38]. Furthermore, oxidative stress affects synaptic transmission and ultimately could leads to a memory dysfunction due to oxidative stress [39]. Therefore, recent researches have been promoted on the prevention of diseases and protective effect of neuronal cells based on the preventing or delaying of cell death. However, the protective effect of apigenin that inhibiting mitochondria-mediated apoptotic signaling pathway in SH-SY5Y neuronal cells has not been studied. The present study is focused on the radical scavenging of apigenin and its neuroprotective 
effects on oxidative stress-induced neuronal cell death by analyzing protein expressions participate in these effect.

The $\mathrm{OH}$ radical, which is the most reactive $\mathrm{ROS}$, can be formed by a Fenton-type reaction, leading to severe damage in adjacent biomolecules [40]. The $\mathrm{O}_{2}^{-}$radical is a precursor of other major $\mathrm{ROS}$ such as $\mathrm{OH}$ radical and $\mathrm{H}_{2} \mathrm{O}_{2}$, which can damage biomolecules and alter physiological functions [41, 42]. Furthermore, overproduction of NO radical has been reported to induce DNA fragmentation, cell membrane damage, and neuronal cell death [43]. In this study, apigenin exerted strong $\mathrm{OH}, \mathrm{O}_{2}^{-}$, and NO radical scavenging activities in a concentrationdependently. Although lacking a hydroxyl group at position 3 and a catechol structure in the B-ring, apigenin has a double bond at the 2, 3 carbon that leads to a more reactive structure possessing anti-oxidant capacities [32, $44,45]$. Therefore, the strong radical scavenging ability imply attributed to the double bond at the 2,3 carbon position.

SH-SY5Y cells are phenotypically and genetically homogeneous cells that can be used to study the relationship between molecules and cell physiology [8]. Therefore, SH-SY5Y cells induced by oxidative stress are extensively used as a model system for investigating neuroprotective properties [9, 10]. Previous studies have indicated that $\mathrm{H}_{2} \mathrm{O}_{2}$ treatment significantly decreased cell viability via an oxidative-dependent apoptotic process [46, 47]. In this study, SH-SY5Y neuronal cells treated with $\mathrm{H}_{2} \mathrm{O}_{2}$ were used as an experimental model to examine the role of apigenin to protect against apoptosis induced by oxidative stress. Apigenin-treated SHSY5Y cells had an antioxidant effect by increasing cell viability and reducing ROS production. In addition, treatment with apigenin significantly decreased levels of $\mathrm{LDH}$ release, indicating that apigenin had protective effects against oxidative damage caused by $\mathrm{H}_{2} \mathrm{O}_{2}$.

The relative ratios of anti-apoptosis and pro-apoptosis Bcl-2 family proteins have been linked to various pathological conditions characterized by cell death [48]. Related proteins of the Bcl-2 family include anti-apoptosis members (Bcl-2, Bcl-w, and Bcl-xL) and pro-apoptosis members (Bax, Bak, Bad, Bik, and Bid) [49]. The BH3 protein is a Bcl-2 homology protein and functions as a trans-dominant inhibitor of Bcl-2. However, the BH3 domain of Bax is heterodimerized with Bcl-2 for migra- tion to the mitochondria via oligomerization to release cytochrome $\mathrm{C}$, thereby causing apoptosis [50, 51]. Therefore, the ratio of the pro-apoptosis protein Bax to the anti-apoptosis protein Bcl-2 is important for regulating the release of caspase activity-inducing factors from mitochondria. Apigenin attenuated doxorubicin-induced cardiotoxicity via the reduction of oxidative stress and apoptosis in male rats, showing a marked decrease in the apoptotic protein Bax and caspase-3 as well as an increase in the anti-apoptosis marker Bcl-2 [52]. Moreover, apigenin inhibited patulin-induced apoptosis in HEK 293 cells via up-regulation of Bcl-2 and down-regulation of Bax, leading to inhibition of caspase activation [53]. In present study, apigenin significantly reduced Bax level and increased Bcl-2 level. Therefore, these results showed that apigenin exerted neuroprotective effects against oxidative stress via the regulation of apoptosis-related protein in SH-SY5Y cells.

Cytochrome $\mathrm{C}$ is released into the cytosol from the mitochondrial intermembrane space, promoting caspase3 activation and eventually causing neuronal apoptosis [54]. In addition, caspase-3 is the most important endcleaving enzyme in the process of apoptosis, cleaving the DNA repair enzyme, PARP, and inducing cell apoptosis [55]. When caspases are activated, that bind with PARP and cleave it, thereby preventing DNA repair and inducing apoptosis. Thus, PARP protein is considered as a marker of apoptosis. The results indicated that apigenin protected against $\mathrm{H}_{2} \mathrm{O}_{2}$ by down-regulation of cytochrome C, cleaved caspase-3, and PARP protein expression in neuronal cells. A previous study indicated that apigenin protects against proteasome inhibitor-induced apoptosis in neuronal cells through regulation of cytochrome C, Bax/Bcl-2, caspases (-8, -9 and -3), and PARP [56]. Apigenin has been also reported to show neuroprotective effects on subarachnoid hemorrhage-induced neuronal apoptosis via down-regulation of Bax and caspase-3 expression levels [57]. In present study, cytochrome C, PARP, and cleaved caspase-3 were up-regulated by treatment with $\mathrm{H}_{2} \mathrm{O}_{2}$ in $\mathrm{SH}-\mathrm{SY} 5 \mathrm{Y}$ cells. However, apigenin treatment inhibited $\mathrm{H}_{2} \mathrm{O}_{2}$-induced cytochrome $\mathrm{C}$, cleaved PARP/PARP, and cleaved caspase-3 protein expressions, suggesting that apigenin exerted its neuroprotective effect through down-regulation of the apoptotic signaling pathway. Apoptosis refers to a complex process involving condensation of the 
nucleus, cytoplasm, and chromatin [58, 59]. Early and late apoptosis can be distinguished by the time of occurrence of apoptosis in the central nervous system. In addition, early apoptosis is related to the proliferation site, whereas late apoptosis is related to the post-mitosis site [60]. Early cell death is characterized by exposure of the translocated phosphatidylserine (PS) to the outer plasma membrane surface [61]. Therefore, flow cytometric analysis using annexin $\mathrm{V}$ and propidium iodide (PI), which is an externalized binding of PS, can confirm an indicator of early cell death. This staining can differentiate between early, late apoptotic and viable cells. Previous study has confirmed that apigenin prevented rate of early apoptosis through double staining with annexin VFITC and PI in oxygen and glucose deprivation/reperfusion-induced neuronal cell injury [62]. Although neuroprotective of apigenin on early-apoptosis and underlying mechanism should be further studied in $\mathrm{H}_{2} \mathrm{O}_{2}$-induced SH-SY5Y neuronal cells, apigenin may contribute to protecting neuronal cells against oxidative stress by regulation of apoptosis signaling pathway involving Bax/ Bcl-2, cytochrome $\mathrm{C}$ release, and caspase activation.

In conclusion, apigenin showed effective $\mathrm{OH}, \mathrm{O}_{2}^{-}$, and NO radical scavenging activity. In particular, apigenin (25, 50, 100, and $250 \mu \mathrm{M})$ showed strong $\mathrm{OH}$ radical scavenging ability, more than 90\%. Furthermore, apigenin increased the cell viability and decreased the ROS generation in $\mathrm{H}_{2} \mathrm{O}_{2}$-treated $\mathrm{SH}$-SY5Y cells. The release of $\mathrm{LDH}$ induced by $\mathrm{H}_{2} \mathrm{O}_{2}$ was also reduced by treatment with apigenin. Moreover, apigenin exhibited anti-apoptotic effects against $\mathrm{H}_{2} \mathrm{O}_{2}$, as shown by down-regulation of cytochrome C, cleaved capase-3, cleaved PARP, and Bax expression levels, and up-regulation of Bcl-2 expression level. In present study, we suggest that apigenin exerts a neuro-protective effect against oxidative stress in SH-SY5Y neuronal cells, and could potentially be used as a preventative agent in neurodegenerative disease.

\section{Acknowledgments}

This work was supported by Gyeongnam National University of Science and Technology Grant in 2020 2022.

\section{Conflict of Interest}

The authors have no financial conflicts of interest to declare.

\section{References}

1. Davalli P, Mitic T, Caporali A, Lauriola A, D'Arca D. 2016. ROS, cell senescence, and novel molecular mechanisms in aging and agerelated diseases. Oxid. Med. Cell. Longev. 2016: 3565127.

2. Del Rio LA. 2015. ROS and RNS in plant physiology: an overview. J. Exp. Bot. 66: 2827-2837.

3. Phaniendra A, Jestadi DB, Periyasamy L. 2015. Free radicals: properties, sources, targets, and their implication in various diseases. Indian J. Clin. Biochem. 30: 11-26.

4. Islam MT. 2017. Oxidative stress and mitochondrial dysfunctionlinked neurodegenerative disorders. Neurol. Res. 39: 73-82.

5. Bhat AH, Dar KB, Anees S, Zargar MA, Masood A, Sofi MA, et al. 2015. Oxidative stress, mitochondrial dysfunction and neurodegenerative diseases; a mechanistic insight. Biomed. Pharmacother. 74: 101-110.

6. Niu X, Zheng S, Liu H, Li S. 2018. Protective effects of taurine against inflammation, apoptosis, and oxidative stress in brain injury. Mol. Med. Rep. 18: 4516-4522.

7. Cobley JN, Fiorello ML, Bailey DM. 2018. 13 Reasons why the brain is susceptible to oxidative stress. Redox Biol. 15: 490-503.

8. Forster Jl, Köglsberger S, Trefois C, Boyd O, Baumuratov AS, Buck $\mathrm{L}$, et al. 2016. Characterization of differentiated SH-SY5Y as neuronal screening model reveals increased oxidative vulnerability. J. Biomol. Screen 21: 496-509.

9. Park HR, Lee H, Park H, Jeon JW, Cho WK, Ma JY. 2015. Neuroprotective effects of Liripope platyphylla extract against hydrogen peroxide-induced cytotoxicity in human neuroblastoma $\mathrm{SH}$ SY5Y cells. BMC Complement. Med. Ther. 15: 171.

10. Zhang B, Cui Y, Wang L, Zhao L, Hou C, Zeng Q, et al. 2018. Autophagy regulates high concentrations of iodide-induced apoptosis in SH-SY5Y cells. Toxicol. Lett. 284: 129-135.

11. Nirmaladevi $D$, Venkataramana $M$, Chandranayaka $S$, Ramesha $A$, Jameel NM, Srinivas C. 2014. Neuroprotective effects of bikaverin on $\mathrm{H}_{2} \mathrm{O}_{2}$-induced oxidative stress mediated neuronal damage in SH-SY5Y cell line. Cell. Mol. Neurobiol. 34: 973-985.

12. Yang R, Wei L, Fu QQ, Wang H, You H, Yu HR. 2016. SOD3 ameliorates $\mathrm{H}_{2} \mathrm{O}_{2}$ induced oxidative damage in $\mathrm{SH}-\mathrm{SY} 5 \mathrm{Y}$ cells by inhibiting the mitochondrial pathway. Neurochem. Res. 41: 1818-1830.

13. Shi MD, Shiao CK, Lee YC, Shih YW. 2015. Apigenin, a dietary flavonoid, inhibits proliferation of human bladder cancer T-24 cells via blocking cell cycle progression and inducing apoptosis. Cancer Cell Int. 15: 33.

14. Chen XJ, Wu MY, Li DH, You J. 2016. Apigenin inhibits glioma cell growth through promoting microRNA-16 and suppression of Bcl-2 and nuclear factor-kappaB/MMP9. Mol. Med. Rep. 14: 23522358.

15. Kowalska I, Adach W, Stochmal A, Olas B. 2020. A comparison of the effects of apigenin and seven of its derivatives on selected biomarkers of oxidative stress and coagulation in vitro. Food. Chem. Toxicol. 136: 111016.

16. Amini R, Yazdanparast R, Ghaffari SH. 2015. Apigenin modulates the expression levels of pro-inflammatory mediators to reduce 
the human insulin amyloid-induced oxidant damages in SK-NMC cells. Hum. Exp. Toxicol. 34: 642-653.

17. Sun X, Min D, Wang Y, Hao L. 2015. Potassium aspartate inhibits SH-SY5Y cell damage and apoptosis induced by ouabain and $\mathrm{H}_{2} \mathrm{O}_{2}$. Mol. Med. Rep. 12: 2842-2848.

18. Sharma A, Ghani A, Sak K, Tuli HS, Sharma AK, Setzer WN, et al. 2019. Probing into therapeutic anti-cancer potential of apigenin: recent trends and future directions. Recent. Pat. Inflamm. Allergy Drug. Discov. 13: 124-133.

19. Zhao L, Wang JL, Liu R, Li XX, Li JF, Zhang L. 2013. Neuroprotective, anti-amyloidogenic and neurotrophic effects of apigenin in an Alzheimer's disease mouse model. Molecules 18: 9949-9965.

20. Li F, Lang F, Zhang H, Xu L, Wang Y, Zhai C, et al. 2017. Apigenin alleviates endotoxin-induced myocardial toxicity by modulating inflammation, oxidative stress, and autophagy. Oxid. Med. Cell. Longev. 2017: 2302896.

21. Zhao L, Wang JL, Wang YR, Fa XZ. 2013. Apigenin attenuates copper-mediated beta-amyloid neurotoxicity through antioxidation, mitochondrion protection and MAPK signal inactivation in an AD cell model. Brain Res. 1492: 33-45.

22. Chung SK, Osawa T, Kawakishi S. 1997. Hydroxyl radical-scavenging effects of spices and scavengers from brown mustard (Brassica nigra). J. Biosci. Biotechnol. Biochem. 61: 118-123.

23. Nishikimi M, Appaji N, Yagi K. 1972. The occurrence of superoxide anion in the reaction of reduced phenazine methosulfate and molecular oxygen. Biochem. Biophys. Res. Commun. 46: 849854.

24. Marcocci L, Packer L, Droy-Lefaix MT, Sekaki A, Gardes-Albert M. 1994. Antioxidant action of Ginkgo biloba extract EGb 761. Methods Enzymol. 234: 462-475.

25. Cathcart R, Schwiers E, Ames BN. 1984. Detection of picomole levels of lipid hydroperoxides using a dichlorofluorescein fluorescent assay. Methods Enzymol. 105: 352-358.

26. Niedzielska E, Smaga I, Gawlik M, Moniczewski A, Stankowicz P, Pera J, et al. 2016. Oxidative stress in neurodegenerative diseases. Mol. Neurobiol. 53: 4094-4125.

27. Cai L, Wang LF, Pan JP, Mi XN, Zhang Z, Geng HJ, et al. 2016. Neuroprotective effects of methyl 3,4-dihydroxybenzoate against TBHP-induced oxidative damage in SH-SY5Y cells. Molecules 21: 1071.

28. Valko M, Jomova K, Rhodes CJ, Kuca K, Musilek K. 2016. Redoxand non-redox-metal-induced formation of free radicals and their role in human disease. Arch. Toxicol. 90: 1-37.

29. Enogieru AB, Haylett W, Hiss DC, Bardien S, Ekpo OE. 2018. Rutin as a potent antioxidant: implications for neurodegenerative disorders. Oxid. Med. Cell. Longev. 2018: 6241017.

30. Achete de Souza G, de Marqui SV, Matias JN, Guiguer EL, Barbalho SM. 2020. Effects of Ginkgo biloba on diseases related to oxidative stress. Planta. Med. 86: 376-386.

31. Pezeshki-Nia S, Asle-Rousta M, Mahmazi S. 2020. Spinacia oleracea L. extract attenuates hippocampal expression of TNF-alpha and IL-1beta in rats exposed to chronic restraint stress. Med. J. Islam. Repub. Iran 34: 10.
32. Salehi B, Venditti A, Sharifi-Rad M, Kregiel D, Sharifi-Rad J, Durazzo A, et al. 2019. The therapeutic potential of apigenin. Int. J. Mol. Sci. 20: 1305.

33. Balez R, Steiner N, Engel M, Muñoz SS, Lum JS, Wu Y, et al. 2016. Neuroprotective effects of apigenin against inflammation, neuronal excitability and apoptosis in an induced pluripotent stem cell model of Alzheimer's disease. Sci. Rep. 12: 31450.

34. Kang SS, Lee JY, Choi YK, Kim GS, Han BH. 2004. Neuroprotective effects of flavones on hydrogen peroxide-induced apoptosis in SH-SY5Y neuroblostoma cells. Bioorg. Med. Chem. Lett. 3: 22612264.

35. Castelli V, Benedetti E, Antonosante A, Catanesi M, Pitari G, Ippoliti R, et al. 2019. Neuronal cells rearrangement during aging and neurodegenerative disease: metabolism, oxidative stress and organelles dynamic. Front. Mol. Neurosci. 28: 132.

36. Wang X, Michaelis EK. 2010. Selective neuronal vulnerability to oxidative stress in the brain. Front. Aging. Neurosci. 2: 12.

37. Zhang L, Yu H, Sun Y, Lin X, Chen B, Tan C, et al. 2007. Protective effects of salidroside on hydrogen peroxide-induced apoptosis in SH-SY5Y human neuroblastoma cells. Eur. J. Pharmacol. 564: 18-25.

38. Mattson MP, Pedersen WA, Duan W, Culmsee C, Camandola S. 1999. Cellular and molecular mechanisms underlying perturbed energy metabolism and neuronal degeneration in Alzheimer's and Parkinson's diseases. Ann. NY Acad. Sci. 893: 154-175.

39. Lee DZ, Chung JM, Chung K, Kang MG. 2012. Reactive oxygen species (ROS) modulate AMPA receptor phosphorylation and cell-surface localization in concert with pain-related behavior. Pain. 153: 1905-1915.

40. AbdulSalam SF, Gurjar PN, Zhu H, Liu J, Johnson ES, Kadekaro AL, et al. 2017. Self-cyclizing antioxidants to prevent DNA damage caused by hydroxyl radical. Chembiochem. 18: 2007-2011.

41. Chiste RC, Freitas M, Mercadante AZ, Fernandes E. 2015. Superoxide anion radical: generation and detection in cellular and non-cellular systems. Curr. Med. Chem. 22: 4234-4256.

42. Sies $\mathrm{H}$, Jones DP. 2020. Reactive oxygen species (ROS) as pleiotropic physiological signalling agents. Nat. Rev. Mol. Cell. Biol. 21: 363383.

43. Bagheri M, Nair RR, Singh KK, Saini DK. 2017. ATM-ROS-iNOS axis regulates nitric oxide mediated cellular senescence. Biochim. Biophys. Acta. Mol. Cell. Res. 1864: 177-190.

44. Singh D, Khan MA, Siddique HR. 2019. Apigenin, a plant flavone playing noble roles in cancer prevention via modulation of key cell signaling networks. Recent. Pat. Anticancer. Drug Discov. 14: 298-311.

45. Wang M, Firrman J, Liu L, Yam K. 2019. A review on flavonoid apigenin: dietary intake, ADME, antimicrobial effects, and interactions with human gut microbiota. Biomed. Res. Int. 2019: 7010467.

46. Zhang L, Yu H, Sun Y, Lin X, Chen B, Tan C, et al. 2007. Protective effect of salidroside on hydrogen peroxide-induced apoptosis in SH-SY5Y human neuroblastoma cells. Eur. J. Pharmacol. 564: 1825. 
47. Tian X, Gao L, An L, Jiang X, Bai J, Huang J, et al. 2016. Pretreatment of MQA, a caffeoylquinic acid derivative compound, protects against $\mathrm{H}_{2} \mathrm{O}_{2}$-induced oxidative stress in $\mathrm{SH}-\mathrm{SY} 5 \mathrm{Y}$ cells. Neurol. Res. 38: 1079-1087.

48. Kale J, Osterlund EJ, Andrews DW. 2018. BCL-2 family proteins: changing partners in the dance towards death. Cell. Death. Differ. 25: 65-80.

49. Opferman JT, Kothari A. 2018. Anti-apoptotic BCL-2 family members in development. Cell. Death. Differ. 25: 37-45.

50. Siddiqui WA, Ahad A, Ahsan H. 2015. The mystery of BCL2 family: $\mathrm{Bcl}-2$ proteins and apoptosis: an update. Arch. Toxicol. 89: 289317.

51. Garner TP, Reyna DE, Priyadarshi A, Chen HC, Li S, Wu Y, et al. 2016. An autoinhibited dimeric form of BAX regulates the $B A X$ activation pathway. Mol. Cell. 63: 485-497.

52. Zare MFR, Rakhshan K, Aboutaleb N, Nikbakht F, Naderi N, Bakhshesh $M$, et al. 2019. Apigenin attenuates doxorubicin induced cardiotoxicity via reducing oxidative stress and apoptosis in male rats. Life. Sci. 232: 116623.

53. Zhong Y, Jin C, Gan J, Wang X, Shi Z, Xia X, et al. 2017. Apigenin attenuates patulin-induced apoptosis in HEK293 cells by modulating ROS-mediated mitochondrial dysfunction and caspase signal pathway Toxicon. 137: 106-113.

54. Qi H, Shuai J. 2016. Alzheimer's disease via enhanced calcium signaling caused by the decrease of endoplasmic reticulummitochondrial distance. Med. Hypotheses 89: 28-31.

55. Xu P, Cai X, Zhang W, Li Y, Qiu P, Lu D, et al. 2016. Flavonoids of Rosa roxburghii Tratt exhibit radioprotection and anti-apoptosis properties via the $\mathrm{Bcl}-2\left(\mathrm{Ca}^{2+}\right) /$ Caspase-3/PARP-1 pathway. Apoptosis 21: 1125-1143.

56. Kim A, Nam YJ, Lee MS, Shin YK, Sohn DS, Lee CS. 2016. Apigenin reduces proteasome inhibition-induced neuronal apoptosis by suppressing the cell death process. Neurochem. Res. 41: 29692980.

57. Han Y, Zhang T, Su J, Zhao Y, Chenchen Wang, Li X. 2017. Apigenin attenuates oxidative stress and neuronal apoptosis in early brain injury following subarachnoid hemorrhage. J. Clin. Neurosci. 40: 157-162.

58. Huang J, May JM. 2006. Ascorbic acid protects SH-SY5Y neuroblastoma cells from apoptosis and death induced by betaamyloid. Brain Res. 1097: 52-58.

59. Guillemain I, Fontès G, Privat A, Chaudieu I. 2003. Early programmed cell death in human NT2 cell cultures during differentiation induced by all-trans-retinoic acid. J. Neurosci. Res. 71: 38-45.

60. Ross ME. 1996. Cell division and the nervous system: regulating the cycle from neural differentiation to death. Trends Neurosci. 19: 62-68.

61. Li P, Zhao QL, Wu LH, Jawaid P, Jiao YF, Kadowaki M, et al. 2014. Isofraxidin, a potent reactive oxygen species (ROS) scavenger, protects human leukemia cells from radiation-induced apoptosis via ROS/mitochondria pathway in p53-independent manner. Apoptosis 19: 1043-1053.

62. Guo H, Kong S, Chen W, Dai Z, Lin T, Su J, et al. 2014. Apigenin mediated protection of OGD-evoked neuron-like injury in differentiated PC12 cells. Neurochem. Res. 39: 2197-2210. 